\title{
KEDUDUKAN GUBERNUR DALAM PENYELENGGARAAN PEMERINTAHAN DAERAH
}

\author{
Abd. Rais Asmar \\ Universitas Islam Negeri Alauddin Makassar \\ Email:rais.asmar@uin-alauddin.ac.id
}

\begin{abstract}
Governor is administration of the district government domiciling as local self government and local field government and responsible to president. Domiciling as local self government relying on form of what overflows of the authority for the shake of efficiency, efektivity, and accountability government in province area and domiciling as local field government of pursuant to mandate to cut short the conduct of the governance. perfection of relation of central government and local government is also determined by how big domicile governor as local field government..
\end{abstract}

Keyword : Local Government, Dimiciling Governor

\begin{abstract}
Abstrak
Gubernur adalah penyelenggara pemerintahan daerah provinsi berkedudukan sebagai kepala daerah provinsi dan wakil pemerintah pusat di daerah dan bertanggung jawab kepada presiden. Kedudukan sebagai kepala daerah bersandar pada bentuk pelimpahan kewenangan demi efisiensi, efektifitas, dan akuntabilitas pemerintahan di wilayah provinsi dan kedudukan sebagai wakil pemerintah pusat berdasarkan mandat untuk memperpendek rentan kendali pemerintahan. Keutuhan hubungan pemerintah pusat dan pemerintah daerah juga ditentukan oleh seberapa besar kedudukan gubernur sebagai wakil pemerintah pusat.
\end{abstract}

Kata Kunci : Pemerintahan Daerah, Kedudukan Gubernur 


\section{PENDAHULUAN}

$\mathrm{H}$

Tubungan antara Pemerintah Pusat dan Pemerintah Daerah dapat bermakna dua yaitu hubungan bertingkat (Sub-ordinat) apabila ada ketergantungan Pemerintah Daerah terhadap Pemerintah Pusat dan hubungan sederajat (Koordinasi) apabila tidak ada ketergantungan satu sama lain. Keduanya diterapkan pada pola hubungan antara tiga entitas pemerintahan di Indonesia yaitu Pemerintah Pusat, Pemerintah Daerah Provinsi, dan Pemerintah Daerah Kabupaten/Kota. Menurut Bambang, hubungan antara ketiganya berlangsung secara inklusif (inklusif authority model). ${ }^{1}$ Penyelenggaraan pemerintahan daerah tetap diawasi oleh pemerintah pusat agar tercipta kesatuan negara.

Pasal 18 ayat (1) UUD NRI 1945 menunjukkan hubungan antara pemerintah pusat dan pemerintah daerah provinsi adalah hubungan bertingkat. Gubernur menjalankan pemerintahan di wilayah provinsi berdasarkan asas dekonsentrasi yaitu pelimpahan kewenangan dari alat perlengkapan negara pusat kepada instansi bawahan guna melaksanakan pekerjaan tertentu dalam penyelenggaraan pemerintahan. ${ }^{2}$ Adapun Pasal 18 ayat (2) UUD NRI 1945 menunjukkan hubungan antara pemerintah daerah provinsi dan pemerintah daerah kabupaten/kota adalah hubungan sederajat karena Gubernur dan Bupati/Walikota sama-sama menjalankan pemerintahan di wilayah masing-masing berdasarkan asas desentralisasi (otonomi daerah) dan tugas pembantuan. Gubernur memiliki kedudukan atau peran ganda yaitu sebagai kepala daerah provinsi (Local Self Government) sekaligus Kepala Wilayah/Wakil Pemerintah Pusat di daerah (Local State Government). ${ }^{3}$ Istilah lainnya sebagai kepala daerah otonom (local self government) dan kepala wilayah administratif (field government), Bupati dan Walikota hanya bertindak sebagai kepala daerah otonom saja. ${ }^{4}$

Kedudukan ganda gubernur di satu sisi dapat menimbulkan konflik hubungan antara pemerintah provinsi dan pemerintah kabupaten/kota tetapi di sisi lain sangat strategis untuk menjaga keseimbangan hubungan antara pemerintah pusat dan pemerintah daerah khususnya antara pemerintah pusat dan pemerintah

\footnotetext{
${ }^{1}$ Murtir Jeddawi, 2006, Hukum Pemerintahan Daerah Suatu Kajian Beberapa Perda Tentang Penanaman Investasi Daerah, Yogyakarta: UII Press Yogyakarta, h.41

${ }^{2}$ Laica Marzuki, 2005, Berjalan-Jalan di Ranah Hukum, Jakarta: Konstitusi Press,h.124

${ }^{3}$ Suryo Sakti Hadiwijoyo, 2011, Gubernur Kedudukan, Peran dan Kewenangannya, Yogyakarta: Graha Ilmu

${ }^{4}$ Ni'matul Huda, 2007, Pengawasan Pusat Terhadap Daerah Dalam Penyelenggaraan Pemerintahan Daerah, Yogyakarta: FH UII Press ,h.72
} 
daerah kabupaten/kota. Pelaksanaan kedudukan gubernur sesuai amanah Pasal 18 ayat (1) UUD NRI 1945 diatur lebih lanjut dalam Undang-Undang No. 23 Tahun 2014 tentang Pemerintahan Daerah (UU 23 Tahun 2014 tentang Pemda). Pasal 4 ayat (1) UU 23 Tahun 2014 tentang Pemda menegaskan status gubernur yaitu selain sebagai kepala daerah provinsi juga merupakan kepala wilayah administratif. Gubernur disini merupakan suatu jabatan beserta pejabatnya yang melaksanakan tugas dan kewenangan tertentu (fungsi). Jabatan merupakan pengertian yuridis dari fungsi, sedangkan fungsi merupakan pengertian yang bersifat sosiologis. ${ }^{5}$ Porsi Tugas gubernur sebagai wakil pemerintah jelas diatur pada Pasal 91 ayat (1) sampai (5) terkait hubungan kewenangan, keuangan, dan pengawasan terhadap pemerintah kabupaten/kota. Dalam sistem rumah tangga daerah akan tampak kedudukan masing-masing pihak dalam penyelenggaraan urusan pemerintahan. Selain itu, hubungan di bidang otonomi akan terkait pula dengan susunan organisasi, keuangan dan pengawasan. ${ }^{6}$

Pada asasnya dalam menjaga keseimbangan hubungan pemerintah pusat dan pemerintah daerah Gubernur menganut Integrated Perfectoral System sebagai bentuk konsistensi pemeliharaan negara kesatuan agar tidak menimbulkan tumpang tindih (Spanning) urusan pemerintahan antara pemerintah pusat dan pemerintah daerah kebupaten/kota dan keseimbangan antar pemerintahan daerah kabupaten/kota. Oleh karena itu, usaha membangun keseimbangan harus diperhatikan dalam konteks hubungan kekuasaan antara pusat dan daerah. Artinya daerah harus dipandang dalam dua kedudukan, yaitu sebagai organ daerah untuk melaksanakan tugas-tugas otonomi dan sebagai agen pemerintah pusat untuk menyelenggarakan urusan pusat di daerah. ${ }^{7}$

Kedudukan ganda gubernur dalam penyelenggaraan pemerintahan daerah dan posisi strategis gubernur dalam sistem pemerintahan merupakan bagian dari obyek permasalahan pada setiap pergantian rezim undang-undang pemerintahan daerah dan pergantian pemerintahan mengenai pengaturan dan pelaksanaannya.

\section{PEMBAHASAN}

Gubernur adalah pejabat di wilayah provinsi berkedudukan sebagai kepala daerah provinsi sekaligus kepala wilayah/wakil pemerintah (pemerintah pusat) di daerah dan bertanggung jawab kepada Presiden menjalankan pemerintahan di

\footnotetext{
5 Jimly Asshiddiqie, 2006, Pengantar Ilmu Hukum Tata Negara, Jakarta:Sekretariat

6 Bagir Manan, 1994, Hubungan Antara Pusat dan Daerah Menurut UUD 1945., Jakarta: Pustaka Sinar Harapan, h.178

${ }^{7}$ Mahfud MD, 2010, Politik Hukum di Indonesia, Jakarta: Rajawali Press,h.95
} 
wilayah provinsi. Pasal 18 ayat (4) UUD NRI 1945 lebih menegaskan kedudukan gubernur sebagai kepala daerah. Akan tetapi, UU 23 Tahun 2014 tentang Pemda lebih menitikberatkan kedudukan gubernur sebagai kepala wilayah berdasarkan asas dekonsentrasi.

Batasan prinsip negara kesatuan yang dianut negara kita bermakna bahwa otonomi yang diberikan kepada gubernur termasuk bupati/walikota tidak bersifat eksklusif tetapi inklusif artinya tetap ada campur tangan pemerintah pusat karena kendali pada pemerintah pusat. Inklusifitas tersebut tampak pada pembagian urusan pemerintahan yang dibagi atas tiga kategori yaitu :

1. Urusan pemerintahan mutlak (absolut) merupakan kewenangan pemerintah pusat

2. Urusan pemerintahan bersama (konkuren) merupakan kewenangan bersama antara pemerintah pusat dan daerah

3. Urusan pemerintahan umum

Kategorisasi diatas menggambarkan bahwa pemerintah pusat memegang kendali atas pelaksanaan urusan pemerintahan di daerah dan otonomi diserahkan melalui pertimbangan efisiensi dan efektivitas pemerintahan. Disinilah kedudukan gubernur sangat dibutuhkan untuk memperpendek rentan kendali pusat terhadap daerah khususnya daerah kabupaten/kota dan menjaga keseimbangan hubungan pusat dan daerah.

Pelaksanaan urusan pemerintahan itu sendiri sebelumnya pada UU 32 Tahun 2004 tentang Pemda masih terdapat kekurangan karena tidak accountability artinya tidak secara eksplisit menjelaskan pasal-pasalnya terkait pembagian urusan pemerintahan antara pemerintahan di Pusat, Provinsi, dan Kabupaten/Kota. Namun, dalam UU 23 Tahun 2014 tentang Pemda telah merinci secara tegas pembagian dan pertanggungjawaban urusan pemerintahan masingmasing. Urusan pemerintahan tersebut dibagi berdasarkan prinsip eksternalitas, akuntabilitas, dan efisiensi dengan memperhatikan keserasian hubungan antar susunan pemerintahan. Peran ganda gubernur berpotensi menimbulkan konflik hubungan antar susunan pemerintahan di bidang urusan pemerintahan diantaranya:

a) Terjadi tumpang tindih urusan pemerintahan antar tingkatan pemerintahan dalam pelaksanaannya

b) Tarik menarik urusan pemerintahan, khususnya urusan yang mempunyai potensi pendapatan (revenue) 
Gubernur berperan dalam menjaga keserasian hubungan antar pemerintahan daerah kabupaten/kota utamanya harus memperhatikan prinsip eksternalitas (Spill over).

Penyelenggaraan urusan pemerintahan yang menjadi kewenangan daerah kabupaten/kota (kewenangan desentralisasi) dan tugas pembantuan di daerah Kabupaten/kota perlu mendapat pengawasan dari gubernur. Gubernur dan bupati/walikota memang tidak terdapat hubungan hirarki dalam menjalankan urusan pemerintahannya masing-masing. Namun, gubernur berwenang untuk mengawasi penyelenggaraan pemerintahan daerah kabupaten/kota. Bentuk pengawasan gubernur tersebut adalah:

a) Bupati/walikota diwajibkan membuat Laporan Penyelenggaraan Pemerintah Daerah (LPPD) dan menyerahkan LPPD kepada gubernur.

b) Pengawasan terhadap Perda kabupaten/kota dan Peraturan Bupati/Walikota pada setiap tahapan prosedur pembentukannya sebagaimana di gambarkan pada tabel berikut:

\begin{tabular}{|c|c|c|c|}
\hline No & $\begin{array}{c}\text { Tahapan Pembentukan Perda } \\
\text { Kabupaten/Kota }\end{array}$ & $\begin{array}{c}\text { Jenis Perda } \\
\text { Kabupaten/Kota }\end{array}$ & $\begin{array}{c}\text { Bentuk } \\
\text { Pengawasan }\end{array}$ \\
\hline 1 & Perancangan & $\begin{array}{l}\text { - } \text { APBD } \\
\text { - } \text { Pajak dan } \\
\text { Retribusi } \\
\text { - RTRW } \\
\text { - RPJPD dan } \\
\text { RPJMD }\end{array}$ & $\begin{array}{l}\text { Evaluasi dan } \\
\text { pembatalan }\end{array}$ \\
\hline 2 & Pembahasan & $\begin{array}{c}\text { Perda Organisasi } \\
\text { dan Perangkat } \\
\text { Daerah }\end{array}$ & Persetujuan \\
\hline 3 & Pengesahan/Pemberlakuan & $\begin{array}{c}\text { Semua Perda } \\
\text { Kabupaten/Kota }\end{array}$ & Pembatalan \\
\hline
\end{tabular}

Sumber : Undang-Undang Nomor 23 Tahun 2014 tentang Pemerintahan Daerah

Gubernur mempunyai kewenangan untuk mengevaluasi dan bahkan membatalkan rancangan Perda APBD kabupaten/kota, Perda pajak dan retribusi, dan Perda tentang tata ruang dan wilayah (RTRW), serta Perda RPJPD/RPJMD. Pengawasan ini dimaksudkan untuk menyelaraskan dengan aturan yang lebih 
tinggi dan kebijakan pemerintah pusat. Gubernur dalam hal ini memiliki peranan untuk menjaga keselarasan hubungan tadi karena sering terjadi tarik menarik urusan antara pemerintah daerah provinsi dan pemerintah daerah kabupaten/kota yang mempunyai potensi pendapatan seperti di bidang pajak dan retribusi dan APBD. Demikian halnya dengan perda strategis seperti RTRW dan organisasi perangkat daerah.

Pelaksanaan kewenangan gubernur sebagai wakil pemerintah dibebankan kepada APBN sedangkan sebagai kepala daerah didanai melalui APBD Provinsi. Hubungan keuangan pusat dan daerah kabupaten/kota juga tidak lepas dari peran gubernur. Sumber pendanaan pemerintah kabupaten/kota sebagian besar diperoleh dari alokasi APBN dalam bentuk DAU, DAK, dan DBH sementara DAK dapat diperoleh melalui rekomendasi gubernur.

Pada dasarnya Kedudukan gubernur sebagai wakil pemerintah yang telah dilegitimasi dalam UU 23 Tahun 2004 tentang Pemda tidak hanya mempermasalahkan kedudukan ganda gubernur tetapi seberapa kuat kedudukan gubernur sebagai wakil pemerintah. Secara geografis, gubernur tidak memiliki wilayah hukum untuk mengurus urusan pemerintahannya. Namun, secara yuridis gubernur berwenang untuk mengurus urusan pemerintahannya. Hal ini yang dijadikan dasar pemikiran untuk tidak memperkuat kedudukan gubernur sebagai wakil pemerintah dengan pertimbangan otonomi dititikberatkan ke daerah kabupaten/kota. Pergantian UU 32 Tahun 2004 tentang Pemda ke UU 23 Tahun 2014 tentang Pemda justru memperlihatkan kecenderungan penguatan kedudukan gubernur sebagai wakil pemerintah. Beberapa kecenderungan penguatan kedudukan gubernur sebagai wakil pemerintah diantaranya:

1) Urusan pemerintahan beralih ke gubernur yaitu di bidang kelautan, pertambangan, dan pendidikan tingkat SMA.

2) Evaluasi dan pembatalan rancangan perda kabupaten/kota sebelumnya hanya terhadap rancangan perda APBD, Perubahan APBD, Pajak dan Retribusi Daerah, dan RTRW. Saat ini ditambah rancangan perda RPJPD dan RPJMD.

3) Memberi persetujuan rancangan perda kabupaten/kota tentang pembentukan dan susunan perangkat daerah kabupaten/kota

4) Memberikan rekomendasi kepada pemerintah pusat atas usulan DAK pada daerah kabupaten/kota di wilayahnya. 
5) Menjatuhkan sanksi kepada penyelenggara pemerintah daerah kabupaten/kota sesuai dengan ketentuan perundang-undangan.

Kebutuhan masyarakat yang semakin meningkat berbanding lurus dengan permasalahan yang dialami oleh pemerintah kabupaten/kota memerlukan campur tangan gubernur selaku wakil pemerintah untuk membantu penyelesaian permasalahan di daerah kabupaten/kota dengan syarat gubernur harus memperhatikan prinsip eksternalitas (lintas kabupaten/kota).

\section{PENUTUP}

Prinsip negara kesatuan mengharuskan keutuhan sistem pemerintahan yang tidak melepaskan kontrol pemerintah pusat terhadap daerah. Namun, kontrol tersebut tidak boleh mengkebiri atau mengecilkan makna desentralisasi yang titik otonominya pada daerah kabupaten/kota. Bagaimanapun juga pemerintah pusat harus menghindarkan negara dari disintegrasi dengan cara kontrol terhadap segala bentuk kegiatan pemerintah daerah. Pemerintah pusat bertanggung jawab penuh dalam pelaksanaan pemerintahan baik di pusat maupun di daerah provinsi dan kabupaten/kota.

Gubernur yang memiliki peran ganda yaitu sebagai kepala daerah provinsi dan kepala wilayah (wakil pemerintah pusat). UU 23 Tahun 2014 tentang Pemda cenderung menitikberatkan peran gubernur sebagai wakil pemerintah melalui penyelenggaraan pemerintahan berdasarkan asas dekonsentrasi. Tugas menjaga keutuhan sistem pemerintahan adalah tujuannya. Adapun penguatan peran gubernur sebagai wakil pemerintah melalui beberapa bentuk campur tangan gubernur terhadap pelaksanaan pemerintahan di kabupaten/kota bertujuan untuk menjaga keseimbangan dan keharmonisan hubungan pemerintahan.

Kedudukan ganda gubernur tersebut harusnya dipahami oleh gubernur sebagai tugas untuk menjaga keutuhan, keseimbangan, dan keharmonisan hubungan antara pemerintah pusat dan daerah dengan tetap menghormati otonomi daerah yang episentrumnya pada pemerintah kabupaten/kota. Sementara itu, Pemerintah kabupaten/kota tidak boleh menafsirkan campur tangan gubernur sebagai bentuk sentralisasi pemerintahan. Akan tetapi, bertujuan untuk membantu menyelesaikan persoalan yang dihadapi oleh pemerintah kabupaten/kota seiring semakin kompleksnya permasalahan masyarakat yang dihadapi. 


\section{DAFTAR PUSTAKA}

Bagir Manan. 1994. Hubungan Antara Pusat dan Daerah Menurut UUD 1945. Jakarta: Pustaka Sinar Harapan

Jimly Asshiddiqie. 2006. Pengantar Ilmu Hukum Tata Negara. Jakarta:Sekretariat Laica Marzuki. 2005. Berjalan-Jalan di Ranah Hukum. Jakarta: Konstitusi Press

Mahfud MD. 2010. Politik Hukum di Indonesia. Jakarta: Rajawali Press

Murtir Jeddawi. 2006. Hukum Pemerintahan Daerah Suatu Kajian Beberapa Perda Tentang Penanaman Investasi Daerah. Yogyakarta: UII Press Yogyakarta

Ni'matul Huda. 2007. Pengawasan Pusat Terhadap Daerah Dalam Penyelenggaraan Pemerintahan Daerah. Yogyakarta: FH UII Press

Suryo Sakti Hadiwijoyo. 2011. Gubernur Kedudukan, Peran dan Kewenangannya. Yogyakarta: Graha Ilmu 